\title{
Preferential Activation and Expansion of Human Peripheral Blood $\gamma \delta$ T Cells in Response to Toxoplasma gondii In Vitro and Their Cytokine Production and Cytotoxic Activity against T. gondii-infected Cells
}

\author{
Carlos S. Subauste, ${ }^{\star \ddagger}$ John Y. Chung, ${ }^{\star}$ Duc Do, “ Anastasia H. Koniaris, ${ }^{\star \ddagger}$ Christopher A. Hunter, ${ }^{\star \ddagger}$ Jose G. Montoya, ${ }^{\star \ddagger}$ \\ Steven Porcelli," and Jack S. Remington** \\ * Department of Immunology and Infectious Diseases, Research Institute, Palo Alto Medical Foundation, Palo Alto, California 94301; \\ ${ }^{\ddagger}$ Division of Infectious Diseases, Department of Medicine, Stanford University School of Medicine, Stanford, California 94305; and \\ "Department of Rheumatology and Immunology, Harvard Medical School, Boston, Massachusetts 02115
}

\begin{abstract}
Studies were conducted to determine if $\gamma \delta$ T cells participate in the immune response to Toxoplasma gondii. Preferential expansion of human $\gamma \delta \mathrm{T}$ cells occurred when peripheral blood $T$ cells from either $T$. gondii-seronegative or seropositive individuals were incubated with autologous PBMC infected with the parasite. That $\gamma \delta \mathrm{T}$ cells proliferated after incubation with infected cells was confirmed using purified of $\gamma \delta \mathrm{T}$ cells. These $T$. gondii-induced $\gamma \delta \mathrm{T}$ cell responses did not require prior exposure to the parasite since $T$ cells obtained from umbilical cord blood from seronegative newborns also exhibited preferential expansion of $\gamma \delta \mathrm{T}$ cells. Cytofluorometric analysis of $T$ cells obtained from either umbilical cord blood or peripheral blood from adults revealed that $\mathrm{V} \gamma \boldsymbol{9}^{+}$and $\mathrm{V} \delta 2^{+} \gamma \delta \boldsymbol{\delta}$ cells responded to stimulation with infected cells. Preferential expansion of $\gamma \delta$ T cells was not restricted by polymorphic determinants of MHC molecules. PBMC that had internalized killed parasites but not PBMC incubated with $T$. gondii lysate antigens also stimulated preferential expansion and activation of $\gamma \delta \mathrm{T}$ cells as assessed by expression of CD25 and HLA-DR molecules. $V \gamma^{+} \boldsymbol{V}^{+} \delta 2^{+} \gamma \delta \mathrm{T}$ cells were cytotoxic for $T$. gondiiinfected cells in an MHC-unrestricted manner, and produced IFN- $\gamma$, IL-2, TNF- $\alpha$, but not IL- 4 when incubated with cells infected with the parasite. These results suggest that rapid induction of a remarkable primary $\gamma \delta \mathrm{T}$ cell response may be important in the early protective immune response to $T$. gondii. (J. Clin. Invest. 1995. 96:610-619.) Key words: $T$ cell receptor - major histocompatibility complex $\cdot$ interferon- $\gamma \cdot$ interleukin-2 - tumor necrosis factor- $\alpha$
\end{abstract}

Address correspondence to Carlos S. Subauste, Research Institute, Palo Alto Medical Foundation, 860 Bryant Street, Palo Alto, CA 94301. Phone: 415-326-8120; FAX: 415-329-9853.

Received for publication 18 July 1994 and accepted in revised form 29 March 1995.

1. Abbreviations used in this paper: CM, complete medium; EBV-LCL, EBV-transformed B lymphoblastoid B cell lines; FKTg, Toxoplasma gondii killed with formalin; HSP, heat shock protein; rIL-2, recombinant IL-2; TCR, T cell receptor; TLA, $T$. gondii lysate antigen; UV, ultraviolet; UVTg, T. gondii attenuated with UV light.

J. Clin. Invest.

(C) The American Society for Clinical Investigation, Inc.

0021-9738/95/07/0610/10 \$2.00

Volume 96, July 1995, 610-619

\section{Introduction}

A small proportion of circulating $\mathrm{T}$ cells express a $\mathrm{T}$ cell antigen receptor (TCR $)^{1}$ composed of a $\gamma \delta$ heterodimer in association with the CD3 complex (1). Although the functions and specificities of these cells are poorly understood, increasing evidence indicates that $\gamma \delta \mathrm{T}$ cells participate in the immune response against certain infectious organisms (2). Some characteristics that distinguish $\gamma \delta \mathrm{T}$ cells from $\alpha \beta$ T cells may have relevance to their potential role in the immune response in vivo. These cells express a limited repertoire of the variable region of the TCR (3), are frequently associated with epithelia in certain species (4), accumulate at sites of infection (5-7), and mature in the fetal thymus before $\alpha \beta$ T cells (8). Indeed, due to these characteristics, it has been proposed that $\gamma \delta \mathrm{T}$ cells may represent a more primitive arm of the $\mathrm{T}$ cell immune response that recognize a limited range of antigens and may act as a first line of defense against certain pathogens and tumors (9).

Toxoplasma gondii is an intracellular parasite that has become a major opportunistic pathogen in patients with defects in cell-mediated immunity $(10,11)$. These patients are at risk of developing reactivation of a chronic (latent) $T$. gondii infection which is usually manifested as toxoplasmic encephalitis (10, 11 ). T cells have been shown to play a critical role in protection against $T$. gondii in mice $(12,13)$ and the relatively high incidence of toxoplasmosis in patients with a defect in T cell function (e.g., patients with Hodgkin's disease and AIDS) provides indirect evidence for the role of $\mathrm{T}$ cells in resistance against this parasite in humans $(10,11)$.

The fact that the natural route of infection with $T$. gondii is through oral ingestion of the parasite would suggest that $\gamma \delta \mathrm{T}$ cells, which are known to be present in the intestinal mucosa, may be one of the first immune cells that would interact with the parasite. Therefore, we were interested to determine whether $\gamma \delta \mathrm{T}$ cells play a role in the immune response against $T$. gondii. In the present study, we show that human peripheral blood $\gamma \delta \mathrm{T}$ cells from either $T$. gondii-seropositive or-seronegative subjects are directly activated by incubation with cells that contain intracellular tachyzoites of $T$. gondii. This activation results in the expression of $\gamma \delta \mathrm{T}$ cell effector functions, including cytolytic activity against $T$. gondii-infected cells and secretion of IFN- $\gamma$, IL-2, and TNF- $\alpha$. These results indicate that a high frequency of $\gamma \delta \mathrm{T}$ cells in all normal individuals is responsive to direct stimulation by $T$. gondii, and suggest an important role for $\gamma \delta \mathrm{T}$ cells in the immune response to this pathogen in humans.

\section{Methods}

Study population. The Stanford Blood Bank supplied buffy coats from heparinized blood of healthy volunteer donors. In addition, umbilical 
cord blood was obtained from placentas of otherwise healthy newborns at Stanford Children's Hospital. T. gondii serology (the agglutination test and Sabin-Feldman dye test for IgG antibodies, and IgM ELISA) were performed as previously described (14-16). This allowed for division of the population into $T$. gondii-seronegative ( 19 donors) and $T$. gondii-seropositive (chronically infected with $T$. gondii [ 5 donors]) healthy adult subjects. The latter subjects had low dye test titers and were negative in the IgM ELISA. All newborns were $T$. gondii-seronegative.

T. gondii organisms and antigens. Tachyzoites of the RH strain were obtained from peritoneal fluid of mice as previously described (17). Mammalian cells were removed by filtration through a Nucleopore polycarbonate membrane (3- $\mu \mathrm{m}$ pore; Costar Scientific Corp., Cambridge, MA) (17). Tachyzoites of the temperature-sensitive mutant ts-4 strain were obtained from infected monolayers of human foreskin fibroblasts (18). Tachyzoites were washed at least three times in large volumes of RPMI 1640 before use. T. gondii lysate antigens (TLA) were obtained by sonication of tachyzoites of the RH strain as described (19). Briefly, mammalian cell-free tachyzoites were sonicated in sterile distilled water. This was followed by centrifugation at $900 \mathrm{~g}$ for $20 \mathrm{~min}$ at $4^{\circ} \mathrm{C}$ to remove debris and unlysed cells. The supernatant was dialyzed against PBS and then used as source of $T$. gondii antigens. For some experiments peritoneal lavage fluids from uninfected mice and tachyzoite-free peritoneal lavage fluids from infected mice (after passage through a $0.45-\mu \mathrm{m}$ filter) were processed as preparations containing $T$. gondii and used as controls.

Purification of $T$ cells. PBMC were isolated by centrifugation on Ficoll-Hypaque gradients (Pharmacia LKB Biotechnology Inc., Piscataway, NJ) as previously described (20). B cell-depleted PBL were obtained by passing PBMC through a nylon wool column (Polysciences Inc., Warrington, PA) (20) followed by overnight incubation in tissue culture flasks (Costar) and collection of nonadherent cells. To purify $T$ cells, PBL were incubated with saturating concentrations of anti-CD16 mAb (Becton Dickinson \& Co., San Jose, CA), and anti-CD56 mAb (Coulter Cytometry, Hialeah, FL) for $1 \mathrm{~h}$ at $4^{\circ} \mathrm{C}$. Cells were then incubated for $1 \mathrm{~h}$ at $37^{\circ} \mathrm{C}$ with a 1:8 dilution of baby rabbit complement (Cedarlane Laboratories Ltd., Hornby, Ontario, Canada). This procedure was repeated once. The resulting cell populations were $>99 \%$ $\mathrm{CD}^{+} \mathrm{T}$ cells by cytofluorometric analysis.

To obtain purified $\gamma \delta \mathrm{T}$ cells, PBL were incubated for $1 \mathrm{~h}$ at $4^{\circ} \mathrm{C}$ with saturating concentrations of anti-CD4 mAb (Dako Corp., Carpinteria, CA). Magnetic beads coated with anti-mouse IgG (Advanced Magnetics, Inc., Cambridge, MA) were added at a bead:cell ratio of 30:1 and incubated for $30 \mathrm{~min}$. at $4^{\circ} \mathrm{C}$ with frequent mixing. Rosetting cells were removed with a magnet (Dynal Inc., Great Neck, NY). Magnetic beads were then added again to remove additional rosetting cells. Cells were then incubated for $1 \mathrm{~h}$ at $4^{\circ} \mathrm{C}$ with saturating concentrations of anti- $\alpha \beta$ mAb (BMA 031; T Cell Diagnostics, Cambridge, MA) and anti-CD8 $\beta$ mAb (2ST85H7; generous gift from Dr. Ellis Reinherz, Dana-Farber Cancer Institute, Boston, MA) (21). This was followed by incubation with magnetic beads coated with anti-mouse IgG (Dynal) and removal of rosetting cells as described above. Remaining cells were subjected to two rounds of complement-dependent lysis using anti-CD16 and anti-CD56 $\mathrm{mAb}$ as described above. This resulted in populations that were $>96 \% \mathrm{CD}^{+} \gamma \delta \mathrm{TCR}^{+} \mathrm{T}$ cells by cytofluorometric analysis. In some experiments, cells obtained after incubation with anti- $\alpha \beta$, anti$\mathrm{CD} 4$, and anti-CD8 $\beta \mathrm{mAb}$ and magnetic beads were labelled with fluorochrome-conjugated anti- $\gamma \delta$ TCR mAb (11F2; Becton Dickinson). $\gamma \delta$ T cells were isolated by FACS ${ }^{\circledR}$ (FACStar ${ }^{\oplus}$ cytofluorometer; Becton Dickinson ). These steps resulted in populations that were $>99 \% \mathrm{CD}^{+}$ $\gamma \delta \mathrm{TCR}^{+}$by cytofluorometric analysis.

Short-term in vitro stimulation of $T$ cells. Either purified $\mathrm{T}$ cells or purified $\gamma \delta \mathrm{T}$ cells were used as responder cells and were cultured in either 24-well or 96-well plates (Costar) in complete medium (CM) consisting of RPMI 1640 supplemented with $100 \mathrm{U} / \mathrm{ml}$ of penicillin, $100 \mu \mathrm{g} / \mathrm{ml}$ of streptomycin, and $10 \%$ dye test-negative pooled human $\mathrm{AB}^{+}$serum (Irvine Scientific, Santa Ana, CA). Unless otherwise stated, responder cells were incubated at a concentration of $5 \times 10^{5}$ cells $/ \mathrm{ml}$. For most experiments, stimulator cells consisted of $\gamma$-irradiated $(3,000$ R) PBMC which had been either infected with tachyzoites of the RH strain of $T$. gondii attenuated with ultraviolet (UV) light (UVTg) as described previously $(20,22,23)$, infected with the temperature-sensitive mutant ts-4 strain of $T$. gondii without UV treatment, incubated with tachyzoites of the RH strain of $T$. gondii killed with formalin (FKTg) as previously described (24), incubated with TLA, or used as uninfected, untreated cells as controls. When PBMC were incubated with any of the three tachyzoite preparations, the percentage of cells with intracellular parasites was determined by light microscopy (20, 23) and stimulator cells were added to responder cells at a responder/ stimulator (infected cells) ratio of 5:1 to 10:1. In preliminary experiments, the optimal concentration of TLA for T cell proliferation was found to be $10 \mu \mathrm{g} / \mathrm{ml}$. In some experiments, purified PHA (Wellcome Diagnostics, Dartford, UK) at a concentration of $0.5 \mu \mathrm{g} / \mathrm{ml}$ was used as mitogenic stimulant. Responder cells were incubated with stimulator cells for $7 \mathrm{~d}$ at $37^{\circ} \mathrm{C}, 5 \% \mathrm{CO}_{2}$. T cells were also incubated with either UVTg-infected or uninfected EBV-transformed B lymphoblastoid B cell lines (EBV-LCL) (generous gift from Dr. Carl Grumet, Stanford University, Stanford, CA). Either infected or uninfected EBV-LCL were fixed with paraformaldehyde and washed extensively before incubation with T cells (25). When $T$. gondii-infected cells were added, a responder/stimulator ratio of 5:1 to 10:1 was used. Effects of short term in vitro stimulations on $\mathrm{T}$ cells were analyzed both by proliferation assays and cytofluorometric analysis.

Generation of $\gamma \delta T$ cell lines and clones. Two methods were used to establish $\gamma \delta \mathrm{T}$ cell lines. PBMC $\left(2.5 \times 10^{6} / \mathrm{ml}\right)$ in $\mathrm{CM}$ were cultured in 24-well tissue culture plates (Linbro; Flow Laboratories, Inc., McLean, VA) at $37^{\circ} \mathrm{C}$ in $5 \% \mathrm{CO}_{2}$. Paraformaldehyde-fixed autologous PBMC that had been infected with UV-attenuated $T$. gondii (stimulator cells ) $\left(2.5 \times 10^{5} / \mathrm{ml}\right)$ were added to each well. This was followed by weekly restimulation with stimulator cells $\left(2.5 \times 10^{5} / \mathrm{ml}\right), \gamma$-irradiated $(5,000 \mathrm{R})$ autologous PBMC $\left(5 \times 10^{5} / \mathrm{ml}\right)$, and recombinant IL-2 (rIL2) (60-100 IU $/ \mathrm{ml}$ ) (generous gift from Chiron Corp., Emeryville, CA ). After $3 \mathrm{w}$ of in vitro culture, $\gamma \delta \mathrm{T}$ cells were purified by negative selection as described above. This resulted in $\mathrm{T}$ cell lines that were $>99 \% \mathrm{CD}^{+} \gamma \delta \mathrm{TCR}^{+}$by cytofluorometric analysis. These $\gamma \delta \mathrm{T}$ cell lines were maintained using the same protocol of re-stimulation.

$\gamma \delta \mathrm{T}$ cell lines and clones were also derived from PBMC $\left(2 \times 10^{6} \%\right.$ $\mathrm{ml}$ ) that had been incubated with UV-attenuated RH tachyzoites (4 $\times 10^{6} / \mathrm{ml}$ ) for $7 \mathrm{~d}$ in CM. Sulfadiazine $(75 \mu \mathrm{g} / \mathrm{ml}$ ) (City Chemical Corp., New York) was added after $24 \mathrm{~h}$ of incubation with $T$. gondii and maintained for $6 \mathrm{~d}$. Thereafter, $\gamma \delta \mathrm{T}$ cells were isolated by positive selection using $\mathrm{FACS}^{\otimes}$ sorting and $\gamma \delta \mathrm{T}$ cell lines and clones were maintained as previously described (26). Briefly, cells were cloned by limiting dilution in 96-well round bottom plates (Linbro) by incubating 0.3 cell/well in CM containing $0.25 \mu \mathrm{g} / \mathrm{ml}$ purified PHA (Wellcome Diagnostics) and rIL-2 (120 IU $/ \mathrm{ml})$ (Chiron Corp.). $\gamma$-irradiated (5,000 R) autologous PBMC $\left(1 \times 10^{5}\right)$ and $\gamma$-irradiated $(7,500 \mathrm{R}) \mathrm{JY}$ EBVLCL $\left(1 \times 10^{4}\right.$ ) (generous gift from Dr. Carol Clayberger, Stanford University, Stanford, CA) were added to each well as feeder cells. The cloning efficiency was $\sim 8 \%$. $\gamma \delta \mathrm{T}$ cell lines and clones $\left(5 \times 10^{5} / \mathrm{ml}\right)$ were maintained by weekly restimulation with $\gamma$-irradiated $(5,000 \mathrm{R})$ autologous PBMC $\left(1 \times 10^{6} / \mathrm{ml}\right), \gamma$-irradiated (7,500 R) JY EBV-LCL $\left(1 \times 10^{5} / \mathrm{ml}\right), 0.25 \mu \mathrm{g} / \mathrm{ml}$ purified PHA, and $\mathrm{rIL}-2(120 \mathrm{IU} / \mathrm{ml}) . \gamma \delta$ $\mathrm{T}$ cell lines and clones were evaluated for cytotoxicity and cytokine production. Results of these functional assays were similar between $\gamma \delta \mathrm{T}$ cell populations obtained with either of the two methods of stimulation.

Cytofluorometric analysis. Lymphocytes obtained both directly from buffy coats and after in vitro culture were studied for expression of different surface markers using the following fluorochrome-conjugated mAbs: anti-CD3, anti- $\alpha \beta$ TCR, anti- $\gamma \delta$ TCR, anti-CD16 (Becton Dickinson \& Co.); anti-V $\gamma 9$ TCR, anti-V $\delta 1$ TCR, anti-V $\delta 2$ TCR (T Cell Diagnostics); anti-CD4, anti-CD8, and anti-HLA DR (Caltag Laboratories, South San Francisco, CA); anti-CD25 and anti-CD56 (Coulter Cytometry). Cells were incubated with the appropriate $\mathrm{mAb}$ for $30 \mathrm{~min}$ at $4^{\circ} \mathrm{C}$. Propidium iodine $(0.5 \mu \mathrm{g} / \mathrm{ml}$ ) (Sigma Chemical Co., St Louis, MO) was added immediately before analyzing the cells with a FACScan cytofluorometer (Becton Dickinson \& Co.). Background fluorescence was assessed by using irrelevant isotype control mAb. Viable cells were identified by exclusion of propidium iodine. In some experi- 


\begin{tabular}{|c|c|c|c|c|c|c|}
\hline \multirow[b]{2}{*}{ Donor } & \multicolumn{3}{|c|}{ Seronegative } & \multicolumn{3}{|c|}{ Seropositive } \\
\hline & 1 & 2 & 3 & 4 & 5 & 6 \\
\hline PBMC* & $\begin{array}{l}218^{\ddagger} \\
(98)\end{array}$ & $\begin{array}{c}485 \\
(208)\end{array}$ & $\begin{array}{c}2,591 \\
(596)\end{array}$ & $\begin{array}{c}2,296 \\
(735)\end{array}$ & $\begin{array}{l}976 \\
(35)\end{array}$ & $\begin{array}{l}539 \\
(68)\end{array}$ \\
\hline PBMC-UVTg & $\begin{array}{l}27,539 \\
(3,047)\end{array}$ & $\begin{array}{l}184,422 \\
(20,990)\end{array}$ & $\begin{array}{l}58,159 \\
(7,604)\end{array}$ & $\begin{array}{l}399,103 \\
(29,383)\end{array}$ & $\begin{array}{l}346,987 \\
(18,945)\end{array}$ & $\begin{array}{r}102,951 \\
(9,099)\end{array}$ \\
\hline PBMC-PHA & $\begin{array}{c}29,830 \\
(2,789)\end{array}$ & $\begin{array}{l}161,660 \\
(10,117)\end{array}$ & $\begin{array}{l}41,179 \\
(4,405)\end{array}$ & $\begin{array}{c}529,254 \\
(10,057)\end{array}$ & $\begin{array}{c}267,443 \\
(10,057)\end{array}$ & $\begin{array}{l}77,168 \\
(3,711)\end{array}$ \\
\hline
\end{tabular}

* T cells were incubated with either unifected PBMC, PBMC infected with UVTg, or PBMC and PHA. ${ }^{\ddagger}$ Results are expressed as mean cpm $\pm(\mathrm{SD})$. Data shown were obtained from six representative donors.

ments only $\mathrm{T}$ cell blasts were analyzed by gating according to forward scatter.

Proliferation assay. For the last $18 \mathrm{~h}$ of the in vitro stimulation, cells were pulsed with $1 \mu \mathrm{Ci}$ of $\left[{ }^{3} \mathrm{H}\right]$ thymidine and harvested onto glass fiber filters using a 96-well cell harvester. Incorporation of $\left[{ }^{3} \mathrm{H}\right]-$ thymidine was measured using a scintillation counter (Beckman Instruments Inc., Fullerton, CA). Results are expressed as the mean cpm of $\left[{ }^{3} \mathrm{H}\right]$ thymidine incorporation of triplicate cultures. Data are also presented as stimulation indices (cpm of cultures with $T$. gondii/cpm of cultures without $T$. gondii).

Cytotoxicity assay. This was performed as previously described $(20$, 23). Target cells consisted of either uninfected EBV-LCL or EBV-LCL infected with UV-attenuated tachyzoites $(20,23)$. Rates of infection ranged from 50 to $70 \% .5 \times 10^{3}$ target cells labeled with ${ }^{51} \mathrm{Cr}$ were added to wells of 96-well U-bottomed plates (Costar) and incubated with different numbers of effector cells for $4 \mathrm{~h}$ at $37^{\circ} \mathrm{C}, 5 \% \mathrm{CO}_{2}$ in RPMI 1640 with $10 \%$ fetal bovine serum (HyClone Laboratories, Inc., Logan, UT). Supernatants were harvested and radioactivity measured using a gamma counter (model $5500 \mathrm{~B}$; Beckman Instruments). The percent specific ${ }^{51} \mathrm{Cr}$ release was calculated using the following formula: $100 \times[($ experimental release - spontaneous release $) /($ maximum release - spontaneous release)]. Percent specific ${ }^{51} \mathrm{Cr}$ release represents the mean from triplicate wells.

Measurement of cytokine production. $\gamma \delta \mathrm{T}$ cell lines were harvested for cytokine analyses 10-14 d after the last addition of stimulator cells and at least $3 \mathrm{~d}$ after the last addition of rIL-2. $\gamma \delta \mathrm{T}$ cells $\left(1 \times 10^{6} \%\right.$ $\mathrm{ml}$ ) were then incubated with either uninfected or $T$. gondii-infected $\gamma$-irradiated $(7,500 \mathrm{R}) \mathrm{JY}$ EBV-LCL $\left(1 \times 10^{6} / \mathrm{ml}\right) . \gamma \delta \mathrm{T}$ cells were also stimulated with uninfected $\gamma$-irradiated JY EBV-LCL plus Con A $(20 \mu \mathrm{g} / \mathrm{ml})$ (Sigma Chemical Co.). Control wells contained either uninfected or $T$. gondii-infected $\gamma$-irradiated JY EBV-LCL without $\gamma \delta$ $T$ cells. Cell culture supernatants were collected at 24 and $48 \mathrm{~h}$ and stored at $-70^{\circ} \mathrm{C}$. Concentrations of IL-2 and IL- 4 in supernatants collected at $24 \mathrm{~h}$, and concentrations of IFN- $\gamma$ and TNF- $\alpha$ in supernatants collected at $48 \mathrm{~h}$ were measured by ELISA (27) (reagents generously provided by Dr. John Abrams, DNAX, Palo Alto, CA).

Statistical analysis. Data were analyzed using Mann-Whitney test or Student's $t$ test.

\section{Results}

Effect of in vitro stimulation with $T$. gondii-infected cells on $\gamma \delta T$ cell populations. The proliferative response of purified resting $\mathrm{T}$ cells upon incubation with either uninfected autologous PBMC or autologous PBMC infected with UVTg was studied. T. gondii was exposed to UV light because this treatment impairs intracellular multiplication of the parasite preventing destruction of infected host cells $(20,22,23)$. In addition, T cells were subjected to mitogenic (PHA) stimulation. As shown in Table I, when compared with $\mathrm{T}$ cells incubated with uninfected autologous PBMC, incubation with autologous PBMC infected with UVTg induced a remarkable proliferative response in T cells from both $T$. gondii-seronegative and seropositive donors. The $T$. gondii-mediated $T$ cell proliferation on day 7 of culture in some donors was comparable in magnitude to the proliferative response induced by PHA (Table I). T cell proliferation was not observed when $T$ cells were stimulated with PBMC incubated with peritoneal lavage fluid preparations from uninfected mice or tachyzoite-free peritoneal lavage fluid preparations from infected animals (data not shown). In addition, the $T$ cell proliferation induced by $T$. gondii-infected cells was not due to potential contamination with endotoxin since addition of polymyxin B $(5 \mu \mathrm{g} / \mathrm{ml})$ did not result in inhibition of this response. Fig. 1 shows the magnitude of $T$. gondiiinduced $\mathrm{T}$ cell proliferation expressed as stimulation indices. No significant difference was observed when the $T$. gondiiinduced proliferation of $\mathrm{T}$ cells from $T$. gondii-seronegative (stimulation indices ranged from 22.5 to 532.6, mean of 137.5) was compared with that of $\mathrm{T}$ cells from seropositive donors (stimulation indices ranged from 28.5 to 355.5 , mean of 156.4) $(P>0.5)$.

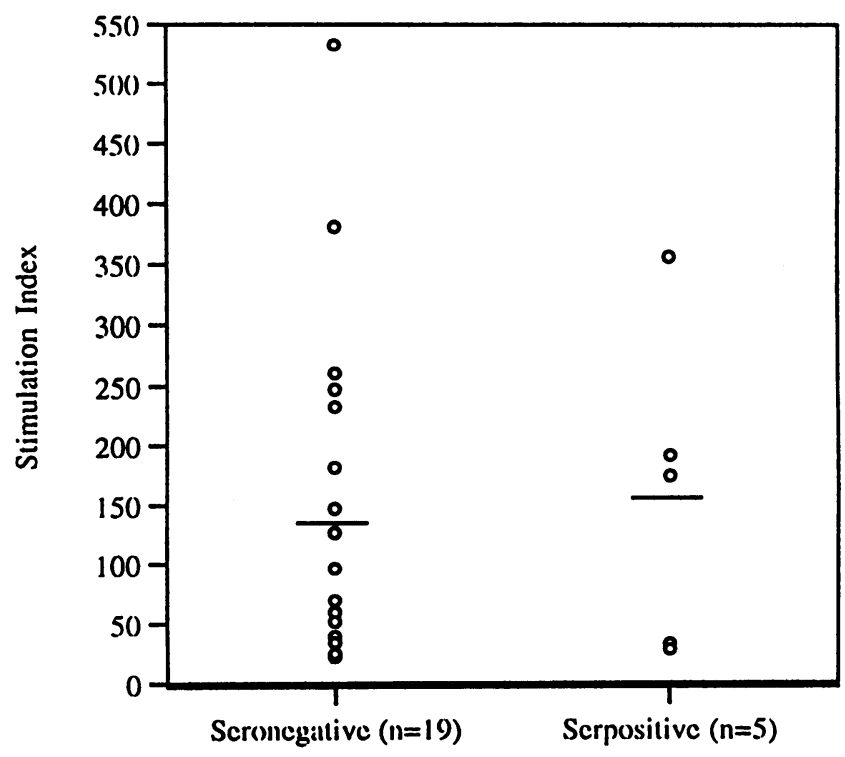

Figure 1. Proliferative response to $T$. gondii-infected cells of $\mathrm{T}$ cells from $19 T$. gondii-seronegative and 5 -seropositive donors. Each dot represents one donor. Horizontal lines represent mean of stimulation indices. 
Table II. $\gamma \delta$ TCR Expression on T Cells before and after $7 d$ of Incubation with Either Uninfected or T. gondii-infected PBMC

\begin{tabular}{|c|c|c|c|c|c|c|}
\hline & \multicolumn{2}{|c|}{ Seronegative $(n=19)$} & \multicolumn{2}{|c|}{ Seropositive $(n=5)$} & \multicolumn{2}{|c|}{ All $(n=24)$} \\
\hline & Percent $\gamma \delta$ & Fold increase* & Percent $\gamma \delta$ & Fold increase & Percent $\gamma \delta$ & Fold increase \\
\hline Day 0 & $3.0(0.4-11.9)^{\ddagger}$ & NA & $4.0(1.9-7.1)$ & NA & $3.3(0.4-11.9)$ & NA \\
\hline \multicolumn{7}{|l|}{ Day 7} \\
\hline PBMC & $0.8(0.1-2.2)$ & 0 & $2.2(1.8-2.6)$ & 0 & $1.1(0.1-2.6)$ & 0 \\
\hline PBMC-UVTg & $31.0(11.2-74.2)$ & $25.7(2.4-127.0)$ & $28.1(12.6-57.0)$ & $18.7(5.2-70.9)$ & $31.4(11.2-74.2)$ & $24.0(2.4-127.0)$ \\
\hline
\end{tabular}

* Fold increase in the numbers of $\gamma \delta \mathrm{T}$ cells. ${ }^{\ddagger}$ Outside parentheses, mean values; inside parentheses, range. NA, not applicable.

To determine the effect of the different stimuli on the phenotypic composition of $\mathrm{T}$ cells, cytofluorometric analysis of purified peripheral blood $T$ cells was performed before and after 7 $\mathrm{d}$ of in vitro stimulation. Percentages of $\gamma \delta \mathrm{T}$ cells in freshly obtained $\mathrm{T}$ cell preparations were within previously reported normal limits (Table II). No significant difference was observed between $T$. gondii-seropositive and seronegative donors ( $P$ $>0.5$ ). Compared with cytofluorometric analysis performed before incubation (day 0 ) and after $7 \mathrm{~d}$ of incubation with uninfected autologous PBMC, incubation with autologous PBMC infected with UVTg resulted in a remarkable increase in the percentage of $\gamma \delta \mathrm{T}$ cells in the T cell preparations of all the donors tested regardless of serological status (Table II). Incubation with PHA did not cause a preferential expansion of $\gamma \delta \mathrm{T}$ cells (data not shown). There did not appear to be any correlation between the percentage of $\gamma \delta \mathrm{T}$ cells before stimulation and the magnitude of the increase in the percentage of these cells after stimulation with UVTg-infected PBMC. The increase in $\gamma \delta \mathrm{T}$ cells was due to cell multiplication since analysis of cell counts and cytofluorometric data performed before and after stimulation with PBMC infected with UVTg indicated that there was a remarkable increase in the absolute number of $\gamma \delta \mathrm{T}$ cells (Table II). On average, the absolute numbers of $\gamma \delta$ $\mathrm{T}$ cells recovered were 24 -fold higher than the initial numbers of $\gamma \delta \mathrm{T}$ cells. There was no significant difference observed in the increase in the number of $\gamma \delta \mathrm{T}$ cells between seronegative and seropositive individuals $(P>0.3)$. The number of $\gamma \delta \mathrm{T}$ cells did not increase when incubation was with uninfected PBMC. The yield of $\alpha \beta$ T cells after incubation with UVTginfected cells was variable. For both $T$. gondii-seronegative and seropositive individuals, the absolute numbers of $\alpha \beta$ T cells recovered ranged from $20 \%$ to $356 \%$ (mean of $118 \%$ ) of the initial numbers of $\alpha \beta \mathrm{T}$ cells.

To rule out the possibility that a $\gamma \delta \mathrm{T}$ cell response would be seen only with $T$. gondii that had been exposed to UV light, PBMC were infected with the temperature-sensitive ts- 4 strain of $T$. gondii. This strain was chosen because its intracellular multiplication is impaired at $37^{\circ} \mathrm{C}(18)$, and thus destruction of infected host cells is prevented. Incubation of $\mathrm{T}$ cells with PBMC infected with the ts-4 strain of $T$. gondii also resulted in preferential expansion of $\gamma \delta \mathrm{T}$ cells (data not shown).

Since the preparations of $\mathrm{T}$ cells used in the studies described above contained both $\alpha \beta$ and $\gamma \delta \mathrm{T}$ cells, the direct effect of $T$. gondii-infected PBMC on $\gamma \delta$ T cells was studied in proliferation assays using preparations of purified $\gamma \delta \mathrm{T}$ cells. As shown in Fig. $2 A, \gamma \delta$ T cells purified by negative selection $\left(>96 \% \mathrm{CD}^{+} \gamma \delta \mathrm{TCR}^{+}\right)$proliferated when incubated with PBMC infected with UVTg. These results were confirmed by using highly purified populations of $\gamma \delta \mathrm{T}$ cells obtained by positive selection $\left(>99 \% \mathrm{CD}^{+} \gamma \delta \mathrm{TCR}^{+}\right)($Fig. $2 \mathrm{~B})$.
Experiments were conducted to study the phenotypic markers of $\gamma \delta \mathrm{T}$ cells after incubation with cells infected with UVTg. Cytofluormetric analysis of $\gamma \delta \mathrm{T}$ cell blasts showed that they were $>98 \% \mathrm{~V} \gamma 9^{+},>91 \% \mathrm{~V} \delta 2^{+},>90 \% \mathrm{CD}^{-},>88 \%$ $\mathrm{CD}^{-}$. To determine further whether $T$. gondii-induced $\gamma \delta \mathrm{T}$ cell response is $\mathrm{V}$-gene related, PBMC from fresh umbilical cord blood from $T$. gondii-seronegative newborns were obtained. This was done because, whereas most $\gamma \delta \mathrm{T}$ cells in peripheral blood from adults are already $\mathrm{V} \gamma 9^{+}$and $\mathrm{V} \delta 2^{+}$, only a fraction of $\gamma \delta \mathrm{T}$ cells in blood from neonates express $\mathrm{V} \gamma 9$ and $\mathrm{V} \delta 2$ chains (28). Incubation of $\mathrm{T}$ cell populations from umbilical cord blood with autologous PBMC infected with
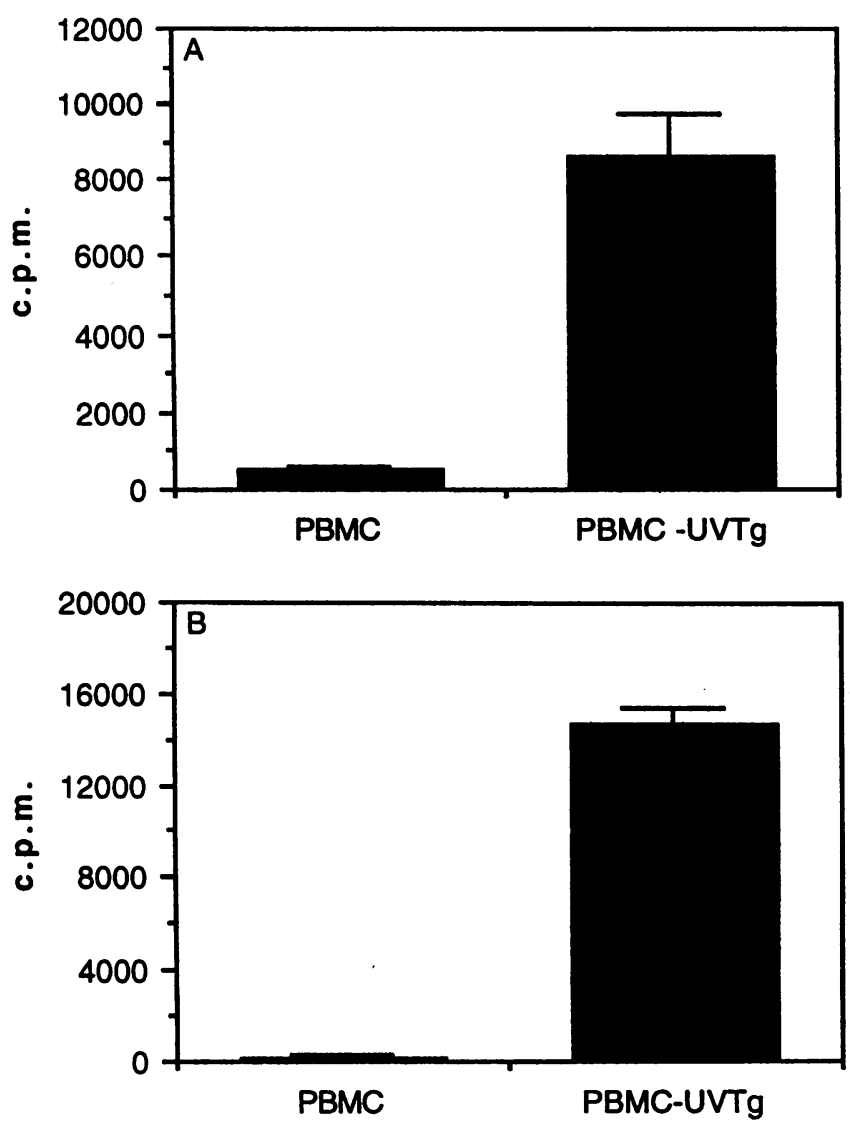

Figure 2. Proliferative response of purified $\gamma \delta \mathrm{T}$ cells to $T$. gondiiinfected cells. $\gamma \delta \mathrm{T}$ cells $\left(1 \times 10^{5} / \mathrm{ml}\right)$ were incubated with either uninfected or T. gondii-infected PBMC (PBMC-UVTg). (A) Results obtained with $\gamma \delta \mathrm{T}$ cells purified by negative selection. $(B)$ Results obtained with $\gamma \delta \mathrm{T}$ cells purified by positive selection. Results are representative of three different donors. 

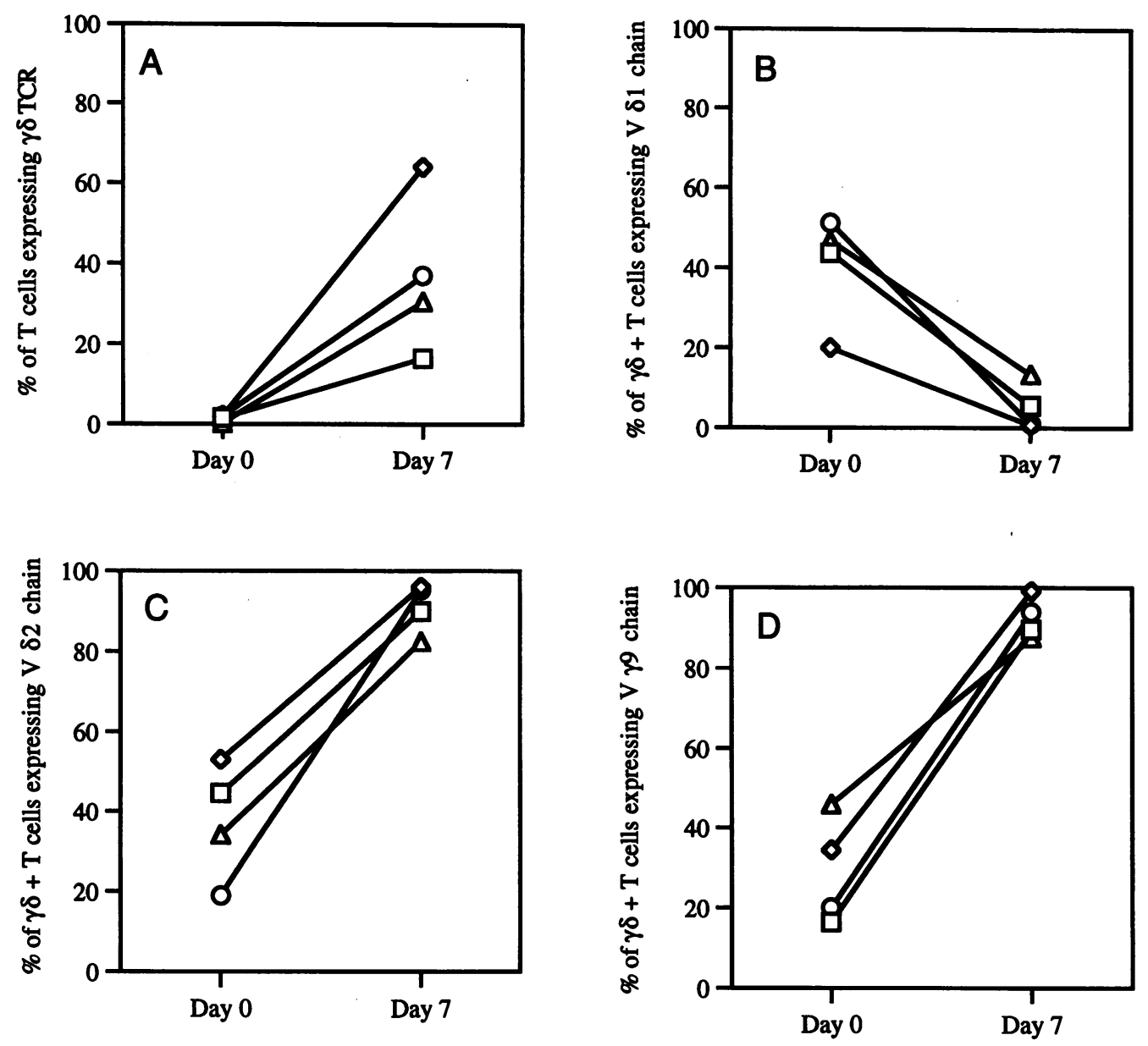

Figure 3. Effect of infection with UVTg on phenotypic composition of T cells from umbilical cord blood. Values are derived by two-color flow cytometry using $\mathrm{mAb}$ specific for CD3, $\gamma \delta \mathrm{TCR}, \mathrm{V} \gamma 9 \mathrm{TCR}, \mathrm{V} \delta 1 \mathrm{TCR}$, and $\mathrm{V} \delta 2 \mathrm{TCR}$. Cytofluorometric analysis was performed before and after 7-d incubation with PBMC infected with UVTg. Each line represents a different donor.

UVTg resulted in preferential expansion of $\gamma \delta \mathrm{T}$ cells (Fig. 3 $A)$. In addition, in all donors tested, infection with UVTg also induced a significant increase in the percentage of $\gamma \delta \mathrm{T}$ cells that expressed the $\mathrm{V} \gamma 9$ and $\mathrm{V} \delta 2$ chains, which accounted for the majority of the $\gamma \delta \mathrm{T}$ cell expansion (Fig. $3, B-D$ ). Incubation of $\mathrm{T}$ cells with either uninfected PBMC or uninfected PBMC plus PHA did not result in expansion or change of the phenotypic composition of $\gamma \delta \mathrm{T}$ cells (data not shown). Thus, in both adults and neonates the $T$. gondii-induced $\gamma \delta \mathrm{T}$ cell expansion is TCR V gene related, strongly pointing to a role for the TCR in this response.

Effects of different preparations of $T$. gondii on $T$ cell responses. The response of $\mathrm{T}$ cells when incubated with either PBMC infected with UVTg, PBMC that had ingested FKTg, or PBMC incubated with TLA was assessed. T cell proliferation using each of the three preparations for stimulation was observed in each of the nine donors tested which included both T. gondii-seronegative and -seropositive subjects (Fig. 4). However, whereas incubation of T cells with PBMC infected with UVTg or PBMC that had internalized FKTg resulted in preferential expansion of the $\gamma \delta \mathrm{T}$ cell population, incubation with TLA did not (Table III). Between 4.5 and $18.5 \%$ (mean of $11.6 \%$ ) of the $\mathrm{T}$ cells were $\gamma \delta \mathrm{TCR}^{+}$after incubation with PBMC that had internalized FKTg, whereas in parallel experiments, between 12.6 and $74.2 \%$ (mean of $36.4 \%$ ) of the $T$ cells were $\gamma \delta \mathrm{TCR}^{+}$after incubation with PBMC infected with UVTg. In addition, incubation of T cells with PBMC that had internalized FKTg resulted in an increase in the number of $\gamma \delta$

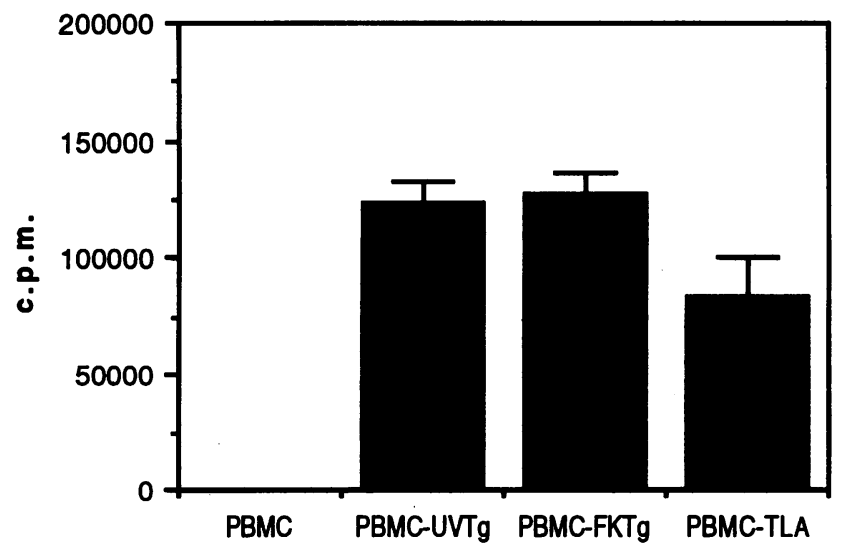

Figure 4. Proliferative response of $\mathrm{T}$ cells to different preparations of T. gondii. T cells were incubated with either uninfected PBMC, PBMC infected with UVTg, (PBMC-UVTg), PBMC incubated with FKTg (PBMC-FKTg), or PBMC and TLA (PBMC-TLA). Results are representative of nine different donors. 
Table III. $\gamma \delta$ TCR Expression on T Cells before and after 7-d Incubation with Different Preparations of T. gondii

\begin{tabular}{lccc}
\hline & \multicolumn{3}{c}{$\% \gamma \delta$ T cells } \\
\cline { 2 - 4 } & Donor 1 & Donor 2 & Donor 3 \\
\hline Day 0 & 6.6 & 3.5 & 2.7 \\
Day 7 & & & \\
PBMC* & 1.2 & 0.4 & 0.7 \\
PBMC-UTVg & 41.6 & 22.0 & 74.2 \\
PBMC-FKTg & 18.6 & 9.8 & 15.5 \\
PBMC-TLA & 2.7 & 2.7 & 2.1 \\
\hline
\end{tabular}

* T cells were incubated with either uninfected PBMC, PBMC infected with UVTs, PBMC incubated with FKTg, or PBMC and TLA. Results are representative of nine different donors.

$T$ cells that ranged from no change to a 50.4-fold (mean of 14.1-fold increase) whereas incubation with PBMC infected with UVTg resulted in an increase that ranged from 4.4- to 127 -fold (mean of 29.8-fold increase). Thus, both cells with intracellular UVTg and with intracellular FKTg induced a $\gamma \delta \mathrm{T}$ cell expansion, whereas cells incubated with a lysate containing soluble parasite antigens did not. This suggested that the intact tachyzoites is required for stimulation of the $\gamma \delta \mathrm{T}$ cell expansion.

The effect of different preparations of $T$. gondii on activation of $\alpha \beta$ and $\gamma \delta$ T cells was assessed by cytofluorometric analysis of the expression of CD25 and HLA-DR molecules (Table IV). Incubation with either PBMC infected with UVTg or PBMC that had internalized FKTg resulted in a significant increase in the percentage of both $\alpha \beta$ and $\gamma \delta$ T cells that bore the CD25 and HLA-DR molecules $(P \leq 0.02)$. Incubation with PBMC plus TLA resulted in a significant increase in the percentage of both $\dot{\alpha} \beta$ and $\gamma \delta \mathrm{T}$ cells that bore the CD25 molecules ( $P$ $\leq 0.02)$ but not HLA-DR molecules $(P \geq 0.06)$. Incubation with either PBMC infected with UVTg or PBMC that had internalized FKTg resulted in a significantly higher percentage of cells that expressed CD25 and HLA-DR molecules in the $\gamma \delta \mathrm{T}$ cell populations than in the $\alpha \beta$ T cell populations $(P \leq 0.04)$ (Table IV). In contrast, the percentage of $\alpha \beta$ and of $\gamma \delta \mathrm{T}$ cells that expressed CD25 or HLA-DR were similar after stimulation with TLA $(P>0.4)$ (Table IV). These results are consistent with the conclusion that cells with intracellular parasites induce a preferential activation of $\gamma \delta \mathrm{T}$ cells.

Effect of MHC on expansion of $\gamma \delta T$ cells. Preliminary studies indicated that $T$. gondii-infected EBV-LCL induced preferential expansion of $\gamma \delta \mathrm{T}$ cells. To determine whether the $T$. gondii-induced expansion of $\gamma \delta \mathrm{T}$ cells is MHC restricted, $T$ cells were incubated with either infected or uninfected MHC mismatched EBV-LCL. For these experiments, EBV-LCL were fixed with paraformaldehyde after infection to avoid any possibility that UVTg present in the EBV-LCL might proliferate and infect autologous $\mathrm{T}$ cells. Preliminary experiments indicated that this treatment completely ablated infectivity of $T$. gondii tachyzoites (data not shown). As indicated in Table V, all MHC mismatched $T$. gondii-infected EBV-LCL induced expansion of $\gamma \delta \mathrm{T}$ cells whereas uninfected EBV-LCL did not, indicating that the $T$. gondii-induced preferential expansion of $\gamma \delta \mathrm{T}$ cells was not restricted by polymorphic MHC determinants.

Cytotoxic activity of $\gamma \delta T$ cells against $T$. gondii-infected cells. $\gamma \delta \mathrm{T}$ cell lines were established and used to assess the
Table IV. Effect of Incubation with Different T. gondii Preparations on Expression of CD25 and HLA-DR Molecules on $\alpha \beta$ and $\gamma \delta T$ Cells

\begin{tabular}{lcclll}
\hline & \multicolumn{2}{c}{$\alpha \beta$ T cells } & & \multicolumn{2}{c}{$\gamma \delta$ T cells } \\
\cline { 2 - 3 } \cline { 5 - 6 } & $\begin{array}{c}\text { Percent } \\
\text { CD25 }\end{array}$ & $\begin{array}{c}\text { Percent } \\
\text { HLA-DR }^{+}\end{array}$ & & $\begin{array}{l}\text { Percent } \\
\text { CD25 }\end{array}$ & $\begin{array}{c}\text { Percent } \\
\text { HLA-DR }^{+}\end{array}$ \\
\hline $\begin{array}{l}\text { Day 0 } \\
\text { Day 7 }\end{array}$ & $1.1 \pm 0.5^{*}$ & $0.9 \pm 0.3$ & & $3.7 \pm 2.4$ & $1.2 \pm 0.9$ \\
PBMC & & & & & \\
PBMC-UVTg & $21.3 \pm 15.9$ & $16.1 \pm 7.4$ & & $63.4 \pm 27.4$ & $75.6 \pm 8.7$ \\
PBMC-FKTg & $63.0 \pm 6.3$ & $32.5 \pm 12.7$ & & $90.3 \pm 2.8$ & $68.9 \pm 15.5$ \\
PBMC-TLA & $36.4 \pm 25.1$ & $22.6 \pm 17.7$ & & $38.2 \pm 23.5$ & $35.4 \pm 19.4$
\end{tabular}

Phenotypic analysis of $\mathrm{T}$ cells before and after $7 \mathrm{~d}$ of in vitro culture was obtained by two-color flow cytometry using mAbs specific for $\alpha \beta$ TCR, $\gamma \delta$ TCR, CD25, and HLA-DR. * Values are mean \pm SD of experiments conducted using $\mathrm{T}$ cells from five different donors. ${ }^{\ddagger} \mathrm{T}$ cells were incubated with either uninfected PBMC, PBMC infected with UVTg, PBMC incubated with FKTg, or PBMC and TLA.

cytotoxic activity against $T$. gondii-infected cells. As shown in Fig. $5 A, \gamma \delta \mathrm{T}$ cells displayed remarkable cytotoxic activity against $T$. gondii-infected cells whereas only minimal cytotoxic activity was observed against uninfected cells. This cytotoxic activity was not MHC restricted since $T$. gondii-infected MHCmismatched target cells were lysed by $\gamma \delta \mathrm{T}$ cells (Fig. $5 \mathrm{~A}$ ). The specific ${ }^{51} \mathrm{Cr}$ release observed in these assays was not due to lysis of extracellular tachyzoites since, under our experimental conditions, the uptake of ${ }^{51} \mathrm{Cr}$ by extracellular parasites was minimal (23). T cell lines used for cytotoxicity assays were $>99 \% \gamma \delta \mathrm{TCR}^{+}$by cytofluorometric analysis, thus it is very unlikely that the observed cytotoxic activity was mediated by contaminating $\alpha \beta$ T cells or natural killer cells. To confirm that $\gamma \delta \mathrm{T}$ cells are cytotoxic for $T$. gondii-infected cells, $\gamma \delta \mathrm{T}$ cell clones were used as effector cells in cytotoxicity assays. These clones were established after in vitro stimulation with $T$. gondii, and were found to express both $\mathrm{V} \gamma 9$ and $\mathrm{V} \delta 2$ chains by cytofluorometric analysis. Fig. $5 B$ shows that $\gamma \delta \mathrm{T}$ cell clones display non-MHC-restricted cytotoxic activity against $T$. gondii-infected cells but not against uninfected cells.

Cytokine production by $\gamma \delta T$ cells. To study the production of cytokines by $\gamma \delta \mathrm{T}$ cells in response to $T$. gondii, either uninfected or $T$. gondii-infected $\gamma$-irradiated EBV-LCL were incubated with $\gamma \delta \mathrm{T}$ cell lines $\left(>99 \% \gamma \delta \mathrm{TCR}^{+}\right.$by cytofluorometric analysis) or $\mathrm{V} \gamma 9^{+} \mathrm{V} \delta 2^{+} \gamma \delta \mathrm{T}$ cell clones. Significant cytokine production was not observed when $\gamma \delta \mathrm{T}$ cells were incubated with uninfected EBV-LCL cells (Table VI). When incubated with $T$. gondii-infected EBV-LCL cells, $\gamma \delta \mathrm{T}$ cells produced significant amounts of IFN- $\gamma$, variable amounts of IL-2 and TNF- $\alpha$ but did not produce detectable IL-4. Cytokines were not detected when $\gamma \delta \mathrm{T}$ cells were incubated with EBVLCL plus tachyzoite-free peritoneal lavage fluid preparations from infected mice (data not shown). $\gamma \delta \mathrm{T}$ cells incubated with Con A secreted not only high amounts of IFN- $\gamma$ and variable amounts of IL-2 and TNF- $\alpha$, but also secreted IL-4 in most cases (Table VI). Supernatants obtained from wells that contained only uninfected or only infected EBV-LCL (without $\gamma \delta$ $\mathrm{T}$ cells) did not contain detectable amounts of any of the cytokines (data not shown). 
Table V. Effect of MHC on T. gondii-induced Preferential Expansion of $\gamma \delta$ T Cells

\begin{tabular}{|c|c|c|c|c|c|c|c|c|c|}
\hline \multicolumn{10}{|c|}{ Percent $\gamma \delta \mathrm{T}$ cells } \\
\hline & \multirow[b]{2}{*}{ Day 0} & \multicolumn{8}{|c|}{ Day 7} \\
\hline & & Autologous & Autologous $\mathrm{Tg}$ & 9010 & 9010-Tg & 9016 & 9016-Tg & 9054 & 9054-Tg \\
\hline Donor 1 & 1.9 & 2.0 & 8.0 & NA & NA & 1.7 & 27.1 & 1.2 & 27.8 \\
\hline Donor 2 & 0.9 & 0.1 & 3.9 & 0.2 & 4.1 & 0.4 & 3.0 & 0.3 & 5.0 \\
\hline
\end{tabular}

T cells were incubated with paraformaldehyde-fixed uninfected or infected cells which were either autologous or MHC mismatched. Donor 1: A1 A3 B35 B41 Bw6 Cw4 DR4 DR10 DR53 DQ1 DQ3. Donor 2: A24 B18 B35 Bw6 Cw1 Cw7 DR4 DR53 DQ8. EBV-LCL $9010:$ A28 B53 Bw4 Cw4 DR15 Dw2 DQ6. EBV-LCL 9016: A2 B51 Bw4 DR16 Dw22 DQ7. EBV-LCL 9054: A2 B44 Bw4 Cw5 DR14 DR52 Dw9 DQ5. Tg, T. gondii-infected; NA, not applicable.

\section{Discussion}

The major mechanism of resistance against $T$. gondii has been shown to be mediated by $\mathrm{T}$ cells $(12,13)$. Both MHC-restricted
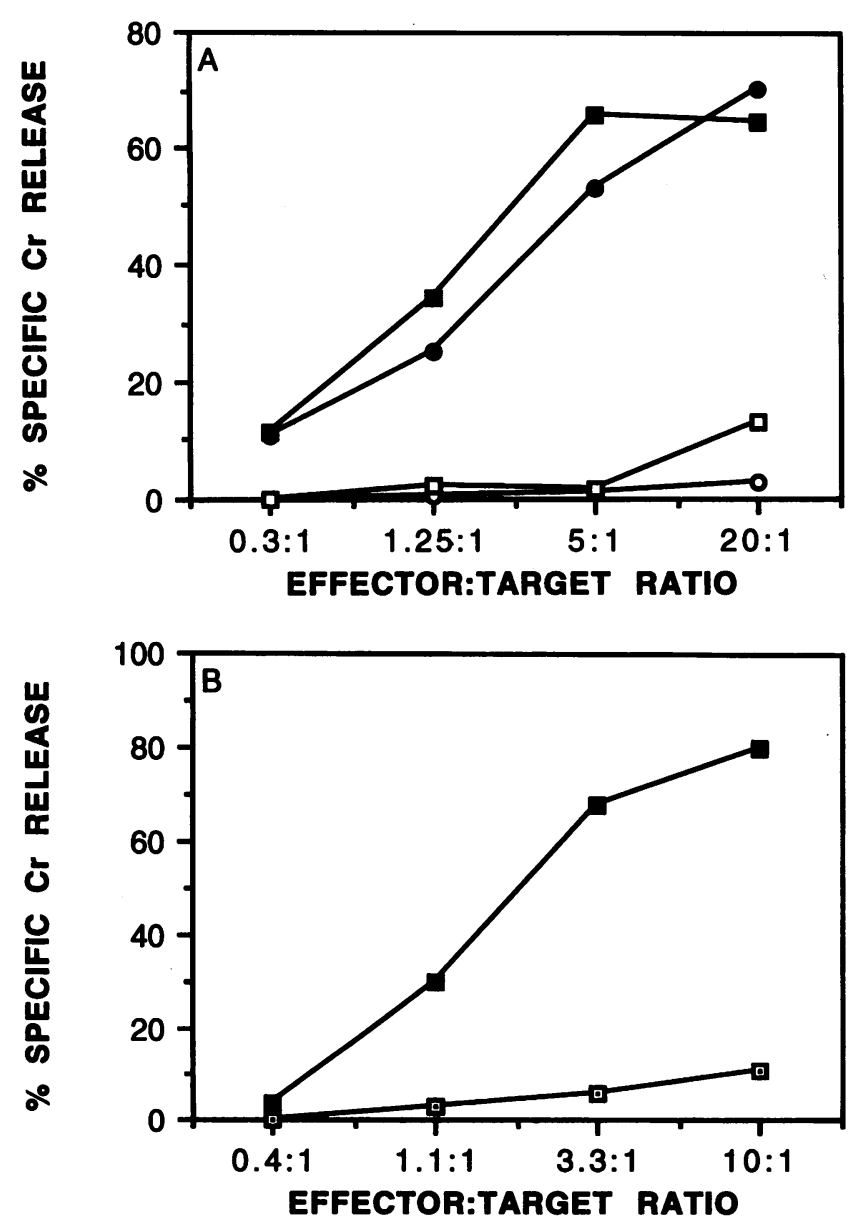

Figure 5. Cytotoxic activity of $\gamma \delta \mathrm{T}$ cells against either uninfected (open symbols) or T. gondii-infected EBV-LCL (closed symbols). (A) Results obtained with a $\gamma \delta \mathrm{T}$ cell line $(R R)$ tested against autologous EBV-LCL (O) (DR4 DR15 DR51 DR53 DQ5 DQ8) or MHC-mismatched EBV-LCL ( $\square$ ) (721.221: no expression of MHC I; DR1 DQ1) (B) Results obtained with a $\mathrm{V} \gamma 9^{+} \mathrm{V} \delta 2^{+} \gamma \delta \mathrm{T}$ cell clone (WT1) (A24 A32 B8 B38 Bw4 Bw6 Cw7 C8 DR4 DR17 DR52 DR53 DQ2 DQ8) tested against MHC-mismatched EBV-LCL (721.221). Results are representative of six separate experiments.
$\mathrm{CD}^{+}$and $\mathrm{CD}^{+} T$. gondii-specific $\mathrm{T}$ cells are involved in the immune response against the parasite $(23,29-31) . \mathrm{CD}^{+}$and $\mathrm{CD}^{+} \mathrm{T}$ cells appear to confer protection by production of IFN$\gamma$ which is a major mediator of host resistance against the parasite (13) and/or through lysis of either cells infected with T. gondii $(23,29-31)$ or extracellular tachyzoites (32). In previous studies of the role of $\mathrm{T}$ cells in resistance against $T$. gondii, $\mathrm{T}$ cells mediating resistance were generally presumed to be $\alpha \beta \mathrm{T}$ cells and the possibility that $\gamma \delta \mathrm{T}$ cells play a part in the immune response has not been assessed. Our results indicate that $T$. gondii provides a strong signal for activation and expansion of human peripheral blood $\gamma \delta \mathrm{T}$ cells from both $T$. gondii-seronegative and -seropositive individuals. In contrast to stimulation of human T cells with PHA or a preparation of soluble TLA, incubation of T cells with cells that had either been infected with viable tachyzoites of $T$. gondii or had internalized killed tachyzoites resulted in preferential expansion of $\gamma \delta \mathrm{T}$ cells. In addition, incubation with $T$. gondii induced activation of $\gamma \delta \mathrm{T}$ cells; after incubation, most of these cells expressed the IL-2 receptor and MHC class II molecules on their surface. Preferential activation of $\gamma \delta \mathrm{T}$ cells occurred when incubation was with cells infected with viable parasites or cells that had

Table VI. Production of Cytokines (IL-2, IL-4, IFN- $\gamma$, and $T N F-\alpha)$ by $\gamma \delta T$ Cells

\begin{tabular}{llrrrr}
\hline & \multicolumn{1}{c}{ Stimulus } & IL-2 & IL-4 & IFN- $\gamma$ & TNF- $\alpha$ \\
\hline Line RR & EBV-LCL & $<19$ & $<39$ & 39 & $<19$ \\
& EBV-LCL-UVTg & 236 & $<39$ & 738 & 495 \\
& EBV-LCL + Con A & 460 & $<39$ & 3,112 & 2,095 \\
Clone WT1 & None & $<19$ & $<39$ & $<19$ & $<19$ \\
& EBV-LCL & $<19$ & $<39$ & $<19$ & $<19$ \\
& EBV-LCL-UVTg & 190 & $<39$ & 796 & 46 \\
& EBV-LCL + Con A & 2,636 & 280 & 4,935 & 1,049 \\
Clone WT4 & None & $<19$ & $<39$ & $<19$ & $<19$ \\
& EBV-LCL & $<19$ & $<39$ & $<19$ & $<19$ \\
& EBV-LCL-UVTg & 52 & $<39$ & 289 & 32 \\
& EBV-LCL + Con A & 197 & 110 & 1,577 & 138
\end{tabular}

$\gamma \delta \mathrm{T}$ cells were stimulated with either uninfected EBL-LCL, EBV-LCL infected with UVTg, or uninfected EBV-LCL plus concanavalin A (Con A). Levels of IL-2, IL-4, IFN- $\gamma$, and TNF- $\alpha$ were measured in culture supernatants using ELISA (sensitivity $>19 \mathrm{pg} / \mathrm{ml}$ for IL-2, IFN- $\gamma$, and TNF- $\alpha ;>39 \mathrm{pg} / \mathrm{ml}$ for IL-4). Results are presented in picograms per milliliter and are representative of four separate experiments. 
internalized killed tachyzoites. These results correlate with the preferential growth of $\gamma \delta \mathrm{T}$ cells after stimulation with these two preparations of cells with intracellular $T$. gondii.

Although our results demonstrate that $T$. gondii induces a preferential activation and expansion of human $\gamma \delta \mathrm{T}$ cells, the parasite also induces activation of $\alpha \beta$ T cells as determined by expression of IL-2 receptor and MHC class II molecules. In this regard, we have recently demonstrated that purified human $\alpha \beta \mathrm{T}$ cells from donors who are seronegative for $T$. gondii antibodies proliferate when incubated with $T$. gondii-infected cells (Subauste, C. S., and J. S. Remington, unpublished observations).

There was less thymidine incorporated by preparations of purified $\gamma \delta \mathrm{T}$ cells than by preparations of unseparated $\mathrm{T}$ cells. One explanation for this might be the lower concentration of purified $\gamma \delta \mathrm{T}$ cells than of unseparated $\mathrm{T}$ cells used in these experiments. Other potential explanations include proliferation of $\alpha \beta \mathrm{T}$ cells in the whole $\mathrm{T}$ cell preparations in response to $T$. gondii and potentiation of the $\gamma \delta \mathrm{T}$ cell proliferative response $\alpha \beta$ T cells (33). It is interesting to note that there was a remarkable $T$ cell proliferative response to $T$. gondii in seronegative individuals. The implications of this phenomenon in the hostparasite relationship are unclear at this point. Elucidation of the mechanism(s) and antigen(s) involved in this response will help address this question. Pertinent to our results is a recent report of a superantigen activity in $T$. gondii (34).

The fact that cells that contained intracellular parasites but not those treated with TLA induced a preferential activation and expansion of $\gamma \delta \mathrm{T}$ cells may be relevant to in vivo infection with $T$. gondii since the parasite resides within cells of multiple tissues in infected persons. Although in our in vitro model both cells with intracellular viable and killed parasites induced a $\gamma \delta$ $\mathrm{T}$ cell response, it appeared that the former induced a stronger signal for $\gamma \delta \mathrm{T}$ cell expansion. Similar observation on the effect of the viability of a microorganism on $\gamma \delta \mathrm{T}$ cell response has been described for Mycobacterium tuberculosis (35). Despite the observation that incubation of $\mathrm{T}$ cells with killed bacteria resulted in activation of $\gamma \delta \mathrm{T}$ cells in vitro $(36,37)$, viability and virulence of bacteria have been reported to be necessary for accumulation of $\gamma \delta \mathrm{T}$ cells at the site of infection in vivo (38).

The absence of a preferential $\gamma \delta \mathrm{T}$ cell response when TLA was used would suggest that for $T$. gondii antigens to induce this response, they either need to originate from intracellular parasites or that the $\gamma \delta \mathrm{T}$ cells recognize a modification of the cells in response to the presence of intracellular tachyzoites. In this regard, it has been reported that $\gamma \delta \mathrm{T}$ cells respond to the highly conserved heat shock proteins (HSP) expressed on stressed cells or present in certain microorganisms $(39,40)$. Pertinent to the immune response to $T$. gondii are studies that detected a $65-\mathrm{kD}$ HSP in peritoneal macrophages from mice infected with $T$. gondii (41). Acquisition of resistance against a lethal dose of a high virulence strain of $T$. gondii was found to be associated with the expression of HSP in peritoneal macrophages. Although $\gamma \delta \mathrm{T}$ cells probably can recognize HSP, it appears that these molecules are not the major ligand for $\gamma \delta \mathrm{T}$ cells reactive to certain pathogens such as $M$. tuberculosis (36). Phosphorylated metabolites of a thymidine-containing nucleotide conjugate isolated from $M$. tuberculosis have recently been reported to be recognized by human $\gamma \delta \mathrm{T}$ cells expressing receptors encoded by $\mathrm{V} \gamma 9$ and $\mathrm{V} \delta 2$ gene segments (42). Thus, whether the ligand(s) responsible for the $T$. gondii-induced $\gamma \delta \mathrm{T}$ cell response are parasite antigens and/or host cell-derived antigens (e.g., HSP) remains to be determined.

Our data indicate that $\gamma \delta \mathrm{T}$ cells from $T$. gondii-seronegative individuals expand when stimulated with cells that had been incubated with $T$. gondii-tachyzoites. It appears unlikely that this response is mediated by prior exposure to cross-reactive antigens since apparently unprimed $\gamma \delta \mathrm{T}$ cells from $T$. gondiiseronegative umbilical cord blood also respond to cells with intracellular $T$. gondii. Therefore, our data suggest that human $\gamma \delta \mathrm{T}$ cells have an inherent reactivity to $T$. gondii. Similar findings have been reported in response to $M$. tuberculosis by $\gamma \delta$ T cells from PPD-negative individuals (36) and by neonatal thymocytes (39). These observations support the possibility that $\gamma \delta \mathrm{T}$ cells act as a first line of defense against certain microbes (9).

Whereas several studies have reported that the response of $\gamma \delta \mathrm{T}$ cells is not MHC restricted (43-45), $\gamma \delta \mathrm{T}$ cells can recognize antigen in association with MHC molecules $(46,47)$. Results of our experiments in which MHC incompatible EBVLCL were used indicate that $T$. gondii-induced preferential expansion of $\gamma \delta \mathrm{T}$ cells and the cytotoxic activity of $\gamma \delta \mathrm{T}$ cells against $T$. gondii-infected cells are not restricted by polymorphic MHC-I or MHC-II molecules. However, we cannot exclude that nonclassical MHC or MHC-like molecules such as CD1 (48) are involved in the $\gamma \delta \mathrm{T}$ cell response to $T$. gondii.

There is evidence that points toward an in vivo role of $\gamma \delta$ $T$ cells in the immune response to infection. In addition to a $\gamma \delta \mathrm{T}$ cell response to in vitro incubation with various bacteria $(5,35,36,38,43-45,49,50)$, Plasmodium falciparum (51, 52) and Leishmania (53), activation of $\gamma \delta \mathrm{T}$ cells in vivo has been reported in infections with $M$. tuberculosis and salmonella $(49,54), \gamma \delta \mathrm{T}$ cells have been found to accumulate in lesions or sites of infection (5-7) and are increased in peripheral blood from patients with certain infections $(55,56) . \gamma \delta \mathrm{T}$ cells have been reported to play a role in protection against Listeria monocytogenes $(7,38,57)$, and Leishmania major (58) in experiments of in vivo depletion of $\gamma \delta \mathrm{T}$ cells and studies that used mice that selectively lack either $\alpha \beta$ or $\gamma \delta \mathrm{T}$ cells. In addition, after in vitro stimulation with $M$. tuberculosis, PBMC obtained from patients with protective and resistant immunity (tuberculin reactors, tuberculosis pleuritis) had higher percentages of $\gamma \delta \mathrm{T}$ cells than those obtained from patients with ineffective immunity (advanced pulmonary tuberculosis and miliary tuberculosis) (50). Finally, $\gamma \delta \mathrm{T}$ cells may also be associated with pathological immune responses in certain diseases (e.g., rheumatoid arthritis, and multiple sclerosis) $(43,59,60)$.

The mechanism(s) by which $\gamma \delta \mathrm{T}$ cells confer protective immunity remain to be determined. We have demonstrated that human $\gamma \delta$ T cells produce IFN- $\gamma$, IL-2, and TNF- $\alpha$ upon stimulation with $T$. gondii-infected cells and that they are cytotoxic for $T$. gondii-infected cells. The importance of these observations lies in the fact that production of these cytokines $(61-63)$ and perhaps lysis of $T$. gondii-infected cells $(20,23,29-31)$ confer protection against $T$. gondii. IFN- $\gamma$ plays a critical role in the protective immune response against the parasite (61). It has been proposed that protective immunity to $T$. gondii is associated with induction of a Th1-type $\mathrm{CD}^{+}{ }^{+} \mathrm{T}$ cell response (64). The differentiation of $\mathrm{CD}^{+} \mathrm{T}$ cells towards a Th1-type response is influenced by cytokines present during antigen priming, with a role for IFN- $\gamma$ in the induction of this response and IL-4 inhibiting it $(65,66)$. It is interesting to note that IFN- $\gamma$ but no IL- 4 could be detected after stimulation of $\gamma \delta \mathrm{T}$ cells with $T$. gondii-infected cells. Pertinent to our data is the recent 
report of production of either IFN- $\gamma$ or IL-4 by $\gamma \delta$ T cells in response to pathogens that induce Th1 or Th2 protective responses respectively (67). Our results suggest that the production of IFN- $\gamma$ by $\gamma \delta$ T cells may be an event of particular importance in the immune response to $T$. gondii, since early production of this cytokine may promote differentiation of $\mathrm{T}$ lymphocytes associated with protective cell-mediated immunity. Finally, the fact that $\gamma \delta$ T cells can be cytotoxic for $T$. gondii-infected cells as well as cells infected with other intracellular organisms (68) suggests that $\gamma \delta \mathrm{T}$ cells may eliminate infected cells.

We observed consistently that most $T$. gondii-reactive $\gamma \delta$ $\mathrm{T}$ cells expressed the $\mathrm{V} \gamma 9$ and $\mathrm{V} \delta 2$ chains. The reactivity of $\mathrm{V} \gamma 9^{+} \mathrm{V} \delta 2^{+} \gamma \delta \mathrm{T}$ cells to $T$. gondii was confirmed in cytotoxicity and cytokine production assays using $\gamma \delta \mathrm{T}$ cell clones. Other microorganisms including $M$. tuberculosis, Francisella tularensis, Plasmodium falciparum, as well as Daudi cells, induce expansion of $\mathrm{V} \gamma_{\gamma} 9^{+} \gamma \delta \mathrm{T}$ cells $(44,51,55,69)$. Whether, given the relatively limited genetic diversity of the $\gamma \delta \mathrm{TCR}, \mathrm{V} \gamma 9^{+} \gamma \delta$ $\mathrm{T}$ cells recognize similar ligands present in all these stimulants remains to be determined. Experiments in which $T$. gondiireactive $\mathrm{V} \gamma 9^{+} \mathrm{V} \delta 2^{+} \gamma \delta \mathrm{T}$ cells are tested against cells infected with other pathogens or tumor cells as targets in cytotoxicity assays will help address this question. It has been proposed that $M$. tuberculosis and $F$. tularensis contain a ligand that acts as a superantigen for human $\gamma \delta$ T cells $(55,70,71)$. In this regard, preparations of soluble $T$. gondii antigens have been reported to contain a superantigen for murine $\alpha \beta$ T cells (34). However, since preparations of soluble parasite antigens did not induce a preferential activation and expansion of human $\gamma \delta \mathrm{T}$ cells, it is unclear if a $T$. gondii superantigen mediates the preferential response of $\gamma \delta \mathrm{T}$ cells that we observed. TCR repertoire analysis to determine the $\mathrm{V}$-(D)-J junctional sequences will be needed to determine whether the stimulation of $\gamma \delta \mathrm{T}$ cells by $T$. gondii is mediated by a superantigen. Nevertheless, the association of a particular $\mathrm{V}$ gene pair with recognition of $T$. gondii by $\gamma \delta \mathrm{T}$ cells supports the hypothesis that this is a specific, TCR-mediated event.

Pertinent to our observations of the in vitro activation and expansion of human $\gamma \delta \mathrm{T}$ cells are the reports of an increase in $\gamma \delta \mathrm{T}$ cells in peripheral blood from patients with symptomatic acute toxoplasmosis $(72,73)$. This increase was mainly due to an increase in $\mathrm{V} \delta 2^{+}$cells and was not observed when retesting was performed during convalesce, suggesting that the $\gamma \delta \mathrm{T}$ cell response was confined to the early phase of the infection. The presence of this in vivo correlate to our results obtained in vitro suggests that the rapid induction of a remarkable primary $\gamma \delta \mathrm{T}$ cell response we observed may be an important component of the early immune response to $T$. gondii. A $\gamma \delta$ T cell response may be particularly relevant to $T$. gondii, since the peroral route is the most common route by which $T$. gondii infection is acquired, and $\gamma \delta \mathrm{T}$ cells present in the intestinal mucosa may be one of the first cell types of the immune system to interact with the parasite.

\section{Acknowledgments}

We are grateful to Drs. Ellis Reinherz, Carl Grumet, Carol Clayberger, and John Abrams for providing us with reagents and EBV-LCL. We thank Chiron Corp. for supplying us with rIL-2.

This work was supported in part by grants AI04717 and AI30230 from the National Institutes of Health, and by a MacArthur Foundation grant in molecular parasitology. C. S. Subauste is the recipient of a grant from the American Foundation for AIDS Research and from the University of California Universitywide AIDS Research Program. C. A. Hunter is the recipient of an Irvington Research Fellowship. S. Porcelli is supported by a Clinical Investigator Award (AR01854) from the National Institutes of Arthritis and Musculoskeletal Diseases.

\section{References}

1. Brener, M. B., J. McLean, D. P. Dialynas, J. L. Strominger, J. A. Smith, F. L. Owen, J. G. Seidman, S. Ip, F. Rosen, and M. S. Krangel. 1986. Identification of a putative second T-cell receptor. Nature (Lond.). 322:145-149.

2. Born, W. K., K. Harshan, R. L. Modlin, and R. L. O'Brien. 1991. The role of $\gamma \delta \mathrm{T}$ lymphocytes in infection. Curr. Opin. Immunol. 3:455-459.

3. Heilig, J. S., and S. Tonegawa. 1986. Diversity of murine gamma genes and expression in fetal and adult T lymphocytes. Nature (Lond.). 322:836-840.

4. Goodman, T., and L. Lefrancois. 1988. Expression of the $\gamma \delta \mathrm{TCR}$ on intestinal $\mathrm{CD}^{+}$intraepithelial lymphocytes. Nature (Lond.). 333:855-858.

5. Modlin, R. L., C. Pirmez, F. M. Hofman, V. Torigian, K. Uyemura, T. H. Rea, B. R. Bloom, and M. B. Brenner. 1989. Lymphocytes bearing antigenspecific $\gamma \delta$ T-cell receptors accumulate in human infectious disease lesions. $\mathrm{Na}$ ture (Lond.). 339:544-548.

6. Inoue, T., Y. Yoshikai, G. Matsuzaki, and K. Nomoto. 1991. Early appearing $\gamma / \delta$-bearing $\mathrm{T}$ cells during infection with Calmette Guerin bacillus. J. Immunol. 146:2754-2762.

7. Hiromatsu, K., Y. Yoshikai, G. Matsuzaki, S. Ohga, K. Muramori, K. Matsumoto, J. A. Bluestone, and K. Nomoto. 1992. A protective role of $\gamma / \delta$ T cells in primary infection with Listeria monocytogenes. J. Exp. Med. 175:49-56.

8. Pardoll, D. M., B. J. Fowlkes, J. A. Bluestone, A. Kruisbeek, W. L. Maloy, J. E. Coligan, and R. H. Schwartz. 1987. Differential expression of two distinct T-cell receptors during thymocyte development. Nature (Lond.). 326:79-81.

9. Janeway, C. A., B. Jones, and A. Hayday. 1988. Specificity and function of $\mathrm{T}$ cells bearing $\gamma \delta$ receptors. Immunol. Today. 9:73-76.

10. Israelski, D. M., and J. S. Remington. 1993. Toxoplasmosis in patients with cancer. Clin. Infect. Dis. 17(Suppl. 2):S423-S435.

11. Wong, S. Y., and J. S. Remington. 1994. Toxoplasmosis in the setting of AIDS. In Textbook of AIDS Medicine. S. Broder, T. C. Merigan, and D. Bolognesi. Williams and Wilkins, Baltimore. 223-257.

12. Suzuki, Y., and J. S. Remington. 1988. Dual regulation of resistance against Toxoplasma gondii infection by Lyt- $2^{+}$and $\mathrm{Lyt}-1^{+}, \mathrm{L3T} 4^{+} \mathrm{T}$ cells in mice. J. Immunol. 140:3943-3946.

13. Gazzinelli, R. T., F. T. Hakim, S. Hieny, G. M. Shearer, and A. Sher 1991. Synergistic role of $\mathrm{CD}^{+}$and $\mathrm{CD} 8{ }^{+} \mathrm{T}$ lymphocytes in IFN- $\gamma$ production and protective immunity induced by an attenuated Toxoplasma gondii vaccine. J. Immunol. 146:286-292.

14. Desmonts, G., and J. S. Remington. 1980. Direct agglutination test for diagnosis of Toxoplasma infection: method for increasing sensitivity. J. Clin Microbiol. 11:562-568.

15. Sabin, A. B., and H. A. Feldman. 1948. Dyes as microchemical indicators of a new immunity phenomenon affecting a protozoon parasite (Toxoplasma) Science (Wash. DC). 108:660-663.

16. Naot, Y., and J. S. Remington. 1980. An enzyme-linked immunosorbent assay for detection of IgM antibodies to Toxoplasma gondii: use for diagnosis of acute acquired toxoplasmosis. J. Infect. Dis. 142:757-766.

17. Dannemann, B. R., V. A. Morris, F. G. Auaujo, and J. S. Remington. 1989. Assessment of human natural killer and lymphokine-activated killer cell cytotoxicity against Toxoplasma gondii trophozoites and brain cysts. J. Immunol. 143:2684-2691.

18. Pfefferkorn, E. R., and L. C. Pfefferkorn. 1976. Toxoplasma gondii: isolation and preliminary characterization of temperature-sensitive mutants. Exp. Parasitol. 39:365-376.

19. Sharma, S. D., J. Mullenax, F. G. Araujo, H. A. Erlich, and J. S. Remington. 1983. Western blot analysis of the antigens of Toxoplasma gondii recognized by human IgM and IgG antibodies. J. Immunol. 131:977-983.

20. Subauste, C. S., L. Dawson, and J. S. Remington. 1992. Human lymphokine-activated killer cells are cytotoxic against cells infected with Toxoplasma gondii. J. Exp. Med. 176:1511-1519.

21. Shiue, L., S. D. Gorman, and J. R. Parnes. 1988. A second chain of human CD8 is expressed on peripheral blood lymphocytes. J. Exp. Med. 168:1993-2005.

22. Grimwood, B. G. 1980. Infective Toxoplasma gondii trophozoites attenuated by ultraviolet irradiation. Infect. Immun. 28:532-535.

23. Subauste, C. S., A. H. Koniaris, and J. S. Remington. 1991. Murine CD8 ${ }^{+}$ cytotoxic $\mathrm{T}$ lymphocytes lyse Toxoplasma gondii-infected cells. J. Immunol. 147:3955-3959.

24. Goldman, M., M. A. Gordon, and R. K. Carver. 1962. Comparison of titers of dye and fluorescence-inhibition tests in the serologic diagnosis of toxoplasmosis. Am. J. Clin. Pathol. 37:541-550.

25. Casten, L. A., and S. K. Pierce. 1988. Receptor-mediated B cell antigen processing. Increased antigenicity of a globular protein covalently coupled to antibodies specific for B cell surface structures. J. Immunol. 140:404-410. 
26. Morita, C. T., C. M. Parker, M. B. Brenner, and H. Band. 1994. TCR usage and functional capabilities of human $\gamma \delta \mathrm{T}$ cells at birth. J. Immunol. 153:3979-3988.

27. Abrams, J. S., M. G. Roncarolo, H. Yssel, U. Anderson, G. J. Gleich, and J. E. Silver. 1992. Strategies of anti-cytokine monoclonal antibody development: immunoassay of IL-10 and IL-5 in clinical samples. Immunol. Rev. 127:5-24.

28. Parker, C. M., V. Groh, H. Band, S. A. Porcelli, C. Morita, M. Fabbi, D. Glass, J. L. Strominger, and M. B. Brenner. 1990. Evidence for extrathymic changes in the T cell receptor $\gamma / \delta$ repertoire. J. Exp. Med. 171:1597-1612.

29. Yano A., F. Aosai, M. Ohta, H. Hasekura, K. Sugane, and S. Hayashi. 1989. Antigen presentation by Toxoplasma gondii-infected cells to $\mathrm{CD} 4{ }^{+}$proliferative T cells and $\mathrm{CD}^{+}$cytotoxic cells. J. Parasitol. 75:411-416.

30. Hakim, F. T., R. T. Gazzinelli, E. Denkers, S. Han, G. M. Shearer, and A. Sher. 1991. CD8 ${ }^{+} \mathrm{T}$ cells from mice vaccinated against Toxoplasma gondii are cytotoxic for parasite-infected or antigen-pulsed host cells. J. Immunol. 147:23102316.

31. Curiel, T. J., E. C. Krug, M. B. Purner, P. Poignard, and R. L. Berens 1993. Cloned human CD4 ${ }^{+}$cytotoxic T lymphocytes specific for Toxoplasma gondii lyse tachyzoite-infected target cells. J. Immunol. 151:2024-2031.

32. Khan, I. A., K. A. Smith, and L. H. Kasper. 1990. Induction of antigenspecific human cytotoxic T cells by Toxoplasma gondii. J. Clin. Invest. 85:18791886.

33. Pechhold, K., D. Wesch, S. Schondelmaier, and D. Kabelitz. 1994. Primary activation of $\mathrm{V} \gamma$ 9-expressing $\gamma \delta \mathrm{T}$ cells by Mycobacterium tuberculosis. Requirement for Th1-type CD4 T cell help and inhibition by IL-10. J. Immunol. 152:4984-4992.

34. Denkers, E. Y., P. Caspar, and A. Sher. 1994. Toxoplasma gondii possesses a superantigen activity that selectively expands murine $\mathrm{T}$ cell receptor $\mathrm{V} \beta 5$ bearing $\mathrm{CD}^{+}$lymphocytes. J. Exp. Med. 180:985-994.

35. Havlir, D. V., J. J. Ellner, K. A. Chervenak, and W. H. Boom. 1991 Selective expansion of human $\gamma \delta \mathrm{T}$ cells by monocytes infected with live $M y c o-$ bacterium tuberculosis. J. Clin. Invest. 87:729-733.

36. Kabelitz, D., A. Bender, S. Schondelmaier, B. Schoel, and S. H. E. Kaufmann. 1990. A large fraction of human peripheral blood $\gamma / \delta^{+} \mathrm{T}$ cells is activated by Mycobacterium tuberculosis but not by its $65-\mathrm{kD}$ heat shock protein. J. Exp. Med. 171:667-679.

37. Munk, M. E., A. J. Gatrill, and S. H. E. Kaufmann. 1990. Target cell lysis and IL-2 secretion by $\gamma / \delta$ T lymphocytes after activation with bacteria. J. Immunol. 145:2434-2439.

38. Skeen, M. J., and H. K. Ziegler. 1993. Induction of murine peritoneal $\gamma / \delta \mathrm{T}$ cells and their role in resistance to bacterial infection. J. Exp. Med. 178 971-984

39. O'Brien, R. L., M. P. Happ, A. Dallas, E. Palmer, R. Kubo, and W. K Born. 1989. Stimulation of a major subset of lymphocytes expressing $\mathrm{T}$ cel receptor $\gamma \delta$ by an antigen derived from Mycobacterium tuberculosis. Cell. 57:667-674.

40. Kun, J., and B. Muller-Hill. 1989. The sequence of a third member of the heat shock protein family in Plasmodium falciparum. Nucleic Acids Res. 17:5384

41. Nagasawa, H., M. Oka, K. Maeda, C. Jian-Guo, H. Hisaeda, Y. Ito, R. A. Good, and K. Himeno. 1992. Induction of heat shock protein closely correlates with protection against Toxoplasma gondii infection. Proc. Natl. Acad. Sci. USA 89:3155-3158.

42. Constant, P., F. Davodeau, M. A. Peyrat, Y. Poquet, G. Puzo, M Bonneville, and J. J. Fournie. 1994. Stimulation of human $\gamma \delta \mathrm{T}$ cells by nonpeptidic mycobacterial ligands. Science (Wash. DC). 264:267-270.

43. Holoshitz, J., F. Koning, J. E. Coligan, J. De Bruyn, and S. Strober. 1989. Isolation of $\mathrm{CD}^{-} \mathrm{CD}^{-}$mycobacteria-reactive clones from rheumatoid arthritis synovial fluid. Nature (Lond.). 339:226-229.

44. Fisch, P., M. Malkovsky, S. Kovats, E. Sturm, E. Braakman, B. S. Klein, S. D. Voss, L. W. Morrissey, R. DeMars, W. J. Welch, et al. 1990. Recognition by human $\mathrm{V} \gamma 9 / \mathrm{V} \delta 2 \mathrm{~T}$ cells of a GroEL homolog on Daudi Burkitt's lymphoma cells. Science (Wash. DC). 250:1269-1273.

45. Boom, W. H., K. A. Chervenak, M. A. Mincek, and J. J. Ellner. 1992. Role of the mononuclear phagocyte as an antigen-presenting cell for human $\gamma \delta$ T cells activated by live Mycobacterium tuberculosis. Infect. Immun. 60:34803488 .

46. Kozbor, D., G. Trinchieri, D. S. Monos, M. Isobe, G. Russo, J. A. Haney, C. Zmijewski, and C. M. Croce. 1989. Human TCR- $\gamma^{+} / \delta^{+}, \mathrm{CD} 8^{+}$T lymphocytes recognize tetanus toxoid in an MHC-restricted fashion. J. Exp. Med. 169:18471851 .

47. Holoshitz, J., L. M. Vila, B. J. Keroack, D. R. McKinley, and N. K. Bayne. 1992. Dual antigenic recognition by cloned human $\gamma \delta \mathrm{T}$ cells. J. Clin. Invest. 89:308-314.

48. Porcelli, S., C. T. Morita, and M. B. Brenner. 1992. CD1b restricts the response of human $\mathrm{CD}^{-} 8^{-} \mathrm{T}$ lymphocytes to a microbial antigen. Nature (Lond.). 360.593-597.

49. Hara, T., Y. Mizuno, K. Takaki, H. Takada, H. Akeda, T. Aoki, M.
Nagata, K. Ueda, G. Matsuzaki, Y. Yoshikai, and K. Nomoto. 1992. Predominant activation and expansion of $\mathrm{V} \gamma$ 9-bearing $\gamma \delta \mathrm{T}$ cells in vivo as well as in vitro in Salmonella infection. J. Clin. Invest. 90:204-210.

50. Barnes P. F., C. L. Grisso, J. S. Abrams, H. Band, T. H. Rea, and R. L. Modlin. 1992. $\gamma \delta$ T lymphocytes in human tuberculosis. J. Infect. Dis. 165:506512.

51. Goerlich R., G. Hacker, K. Pfeffer, K. Heeg, and H. Wagner. 1991 Plasmodium falciparum merozoites primarily stimulate the $\mathrm{V} \gamma 9$ subset of human $\gamma / \delta$ T cells. Eur. J. Immunol. 21:2613-2616.

52. Goodier, M., P. Fey, K. Eichmann, and J. Langhorne. 1992. Human peripheral blood $\gamma \delta \mathrm{T}$ cells respond to antigens of Plasmodium falciparum. Int Immunol. 4:33-41.

53. Russo, D. M., R. J. Armitage, M. Barral-Netto, A. Barral, K. H. Grabstein, and S. G. Reed. 1993. Antigen-reactive $\gamma \delta \mathrm{T}$ cells in human leishmaniasis. $J$. Immunol. 151:3712-3718.

54. Janis, E. M., S. H. E. Kaufmann, R. H. Schwartz, and D. M. Pardoll. 1989. Activation of $\gamma \delta \mathrm{T}$ cells in the primary immune response to Mycobacterium tuberculosis. Science (Wash. DC). 244:713-716.

55. Sumida, T., T. Maeda, H. Takahashi, S. Yoshida, F. Yonaha, A. Sakamoto, H. Tomioka, T. Koike, and S. Yoshida. 1992. Predominant expansion of V $\gamma 9$ / V $\delta 2 \mathrm{~T}$ cells in a tularemia patient. Infect. Immun. 60:2554-2558.

56. Ho, M., H. K. Webster, P. Tongtawe, K. Pattanpanyasat, and W. P Weidanz. 1990. Increased $\gamma \delta \mathrm{T}$ cells in acute Plasmodium falciparum malaria. Immunol. Lett. 25:139-142.

57. Mombaerts, P., J. Arnoldl, F. Russ, S. Tonegawa, and S. H. E. Kaufmann. 1993. Different roles of $\alpha \beta$ and $\gamma \delta$ T cells in immunity against an intracellular bacterial pathogen. Nature (Lond.). 365:53-56.

58. Rosat, J. P., H. R. MacDonald, and J. A. Louis. 1993. A role for $\gamma \delta^{+}$T cells during experimental infection of mice with Leishmania major. J. Immunol. 150:550-555.

59. Brennan, F. M., M. Londei, A. M. Jackson, T. Hercend, M. B. Brenner, R. N. Maini, and M. Feldmann. 1988. T cells expressing $\gamma \delta$ chain receptors in rheumatoid arthritis. J. Autoimmun. 1:319-326.

60. Wucherpfennig, K. W., J. Newcombe, H. Li, C. Keddy, M. L. Cuzner and D. A. Hafler. 1992. $\gamma \delta$ T-cell receptor repertoire in acute multiple sclerosis lesions. Proc. Natl. Acad. Sci. USA. 89:4588-4592.

61. Suzuki, Y., M. A. Orellana, R. D. Schreiber, and J. S. Remington. 1988. Interferon- $\gamma$ : the major mediator of resistance against Toxoplasma gondii. Science (Wash. DC). 240:516-518

62. Johnson, L. L. 1992. A protective role for endogenous tumor necrosis factor in Toxoplasma gondii infection. Infect. Immun. 60:1979-1983.

63. Sharma, S. D., J. M. Hofflin, and J. S. Remington. 1985. In vivo recombinant interleukin 2 administration enhances survival against lethal challenge with Toxoplasma gondii. J. Immunol. 135:4160-4163.

64. Gazzinelli, R., Y. Xu, S. Hieny, A. Cheever, and A. Sher. 1992. Simultaneous depletion of $\mathrm{CD4}^{+}$and $\mathrm{CD8} 8^{+} \mathrm{T}$ lymphocytes is required to reactivate chronic infection with Toxoplasma gondii. J. Immunol. 149:175-180.

65. Seder, R. A., R. Gazzinelli, A. Sher, and W. E. Paul. 1993. Interleukin 12 acts directly on $\mathrm{CD}^{+} \mathrm{T}$ cells to enhance priming for interferon $\gamma$ production and diminishes interleukin 4 inhibition of such priming. Proc. Natl. Acad. Sci. USA. 90:10188-10192.

66. Seder, R. A., W. E. Paul, M. M. Davis, and B. Fazekas de St. Groth. 1992 The presence of interleukin 4 during in vitro priming determines the lymphokineproducing potential of CD4 ${ }^{+} \mathrm{T}$ cells from $\mathrm{T}$ cell receptor transgenic mice. J. Exp. Med. 176:1091-1098.

67. Ferrick, D. A., M. D. Schrenzel, T. Mulvania, B. Hsieh, W. G. Ferlin, and H. Lepper. 1995. Differential production of interferon- $\gamma$ and interleukin-4 in response to Th1- and Th2-stimulating pathogens by $\gamma \delta \mathrm{T}$ cells in vivo. Nature (Lond.). 373:255-257.

68. Bukowski, J. F., C. T. Morita, and M. B. Brenner. 1994. Recognition and destruction of virus-infected cells by human $\gamma \delta$ T CTL. J. Immunol. 153:51335140 .

69. Kabelitz, D., A. Bender, T. Prospero, S. Wesselborg, O. Janssen, and K. Pechhold. 1991. The primary response of human $\gamma / \delta^{+}$T cells to Mycobacterium tuberculosis is restricted to V $\gamma$ 9-bearing cells. J. Exp. Med. 173:1331-1338.

70. Pfeffer, K., B. Schoel, N. Plesnila, G. B. Lipford, S. Kromer, K. Deusch, and $\mathrm{H}$. Wagner. 1992. A lectin-binding, protease-resistant mycobacterial ligand specifically activates $\mathrm{V} \gamma 9^{+}$human $\gamma \delta \mathrm{T}$ cells. J. Immunol. 148:575-583.

71. Band, H., S. A. Porcelli, G. Panchamoorthy, J. McLean, C. T. Morita, S. Ishikawa, R. L. Modlin, and M. B. Brenner. 1991. Antigens and antigen-presenting molecules for $\gamma \delta$ T cells. Curr. Top. Microbiol. Immunol. 173:229-234.

72. De Paoli, P., G. Basaglia, D. Gennari, M. Crovatto, M. L. Modolo, and G. Santini. 1992. Phenotypic profile and functional characteristics of human gamma and delta T cells during acute toxoplasmosis. J. Clin. Microbiol. 30:729731

73. Scalise, F., R. Gerli, G. Castelucci, F. Spinozzi, G. M. Fabietti, S. Crupi, L. Sensi, R. Britta, R. Vaccaro, and A. Bertotto. 1992. Lymphocytes bearing the $\gamma \delta \mathrm{T}$-cell receptor in acute toxoplasmosis. Immunology. 76:668-670. 